\title{
Understanding Of Family To Choose The Place Of Labor In Tanjung Health Center Working Area
}

\author{
Fitri Yuliana $^{1}$, R. Hariadi Widodo ${ }^{2}$, Endah Septiati Dwi Ningsih ${ }^{3}$ \\ \{yuliana_fitri34@yahoo.co.id\} \\ Midwifery Departmen, Faculty of Health Sari Mulia University, Banjarmasin, Indonesia ${ }^{1}$ \\ Nursing Department, Faculty of Health Sari Mulia University, Banjarmasin, Indonesia ${ }^{2}$ \\ Tanjung Health Center, Tabalong Regency, Indonesia ${ }^{3}$
}

\begin{abstract}
The choice of labor place that is not ideal will have a direct impact on mother and baby health. It can be happened because each pregnancy has risk of an emergency situation during labor. Although labor has been assisted by health workers, many deliveries still carried out at home and still happened in Tanjung Health Center area. Accordingly, we need to know more deeply about the family understanding and consideration to choose the place of labor in Tanjung Health Center working area. This research is a qualitative research with case study approach and purposive sampling technique.

The research was carried out by collecting data through in-depth interview with four main informants as head of family and nine triangulation informants in the working area of Tanjung Health Center. The data was analyzed by interactive model. The results of this study showed Families view the labor as an important event including feeling of sadness, fear, and anxiety. In decision making of helper and labor place, the family have to consider carefully about the cost, family trust in midwife who will help the labor process, so it can be concluded that the understanding of family in choosing the place of labor is motivated by economic factor, trust in health workers in assisting childbirth, and information that was obtained by the family from health workers.
\end{abstract}

Keyword: Economic factors, Family beliefs, Family understanding, Information, Place of deliver

\section{Introduction}

Health status of a nation can be measured from the maternal mortality rate, infant mortality rate and life expectancy. According to the 2012 Indonesian Demographic Survey Report (SDKI), the Maternal Mortality Rate (MMR) is 359 / 100,000 live births and the Infant Mortality Rate (IMR) is 32/1000 live births. The causes of maternal deaths in Indonesia are bleeding, preeclampsia, long term labor, abortion and infection. The five causes of death are supported by a delay factor commonly referred to as 3 late (3T), are ate recognizing danger signs/determining problems, being late in making decisions to be referred and late getting adequate assistance in health facilities [1].

The choice of place and birth attendant that is not right will have a direct impact on the health of the mother and the delivery process so that if complications occur there can result in morbidity and death of both mother and baby. Midwives in carrying out their duties have approached the family, providing counseling, education, and providing information to mothers 
and families so that pregnancy and childbirth can run normally and without complications. This was done with the aim of increasing coverage of deliveries by health workers in health facilities, but coverage of deliveries by health workers did not change significantly. For three late that usually occur in cases of deliveries performed at maternity mothers' homes [2].

Based on the 2015 Indonesian Health Profile Data, coverage of births by health workers has increased, that is $88.55 \%$ and delivery assistance in health facilities is still $70.4 \%$. The Ministry of Health has a target of delivering labor assisted by health workers in health facilities by $100 \%$. The increased coverage of deliveries by health workers is not matched by the coverage of deliveries in health facilities [3].

According to omit PWS (Local Area Monitoring) Data Report, Health of Mother-child Tanjung Health Center, Tanjung Subdistrict, Tabalong Regency in 2015 and 2016 which oversees five target villages, there are three target villages that have not reached the $100 \%$ target for delivery in health facilities. Based on information from midwives who work in one of the villages in the Puskesmas Tanjung work area, it was found that the mother gave birth at home because she felt more comfortable and free, did not bother, did not leave her children and other family members, and the important thing was to give birth with health workers even at home. Other information obtained from one of the village heads in the working area of the Tanjung Puskemas said that there were some people who did not understand the importance of childbirth assisted by health workers and child birth in health facilities, especially those who lived somewhat remote, so lacked information, first experience during childbirth was easy and normal a husband's decision and a matter of cost $[4,5]$. Based on these problems, it is necessary to examine the perceptions of families in the working area of the Tanjung Subdistrict Health Center in choosing a place of delivery.

\section{Materials And Methods}

The method used in this research is qualitative with a case study approach through indepth interviews, as well as documentary studies. The sampling technique in this study used a purposive sampling method by in-depth interviews with key informants, that is two head of family who played a role in the decision to choose maternity at home and two family heads who played a role in the decision to choose maternity in a health facility, as well as nine triangulation informants consisting of two women bearing the wife's wife families who choose to give birth at home, two mothers who give birth to wives of family heads who choose to give birth at a health facility, two village midwives, one KIA Coordinating Midwife, one posyandu cadre and one community leader/village leader. The research instrument used semi-structured interview guidelines, including open-ended questions, stationery, and conversation recorder for documentation. Data analysis in this study uses an interactive model, that is: data collection, data reduction, data display, and making conclusions. The data quality test in this study was carried out through triangulation with the reliability of the agreement between the description stated by the research subject and the actual conditions.

\section{Results}

\subsection{Family views about the events of childbirth}


The information obtained revealed that all maint informants viewed the birth event as an important:

"event experienced in life, where the process was passed through with fear, anxiety, and sadness when something happened to his wife and baby, so that in the future decided not to have more children. Feelings of sadness because childbirth is a struggle between life and death and the wife should give birth at the Hospital because of cost factors forced to choose to give birth at home." (main informants $1,2,3,4$ )

The results of the interview with triangulation information contained the same statement as the main informants about their view of the childbirth event, which is:

"an event filled with pain and fear that they were worried that something unexpected would happen. A different statement is expressed that childbirth is an ordinary event, and ordinary, there is no feeling of fear and anxiety, a sense of confidence and resignation, pray to God Almighty for its smoothness and safety, so it is not too much attention." (triangulation informants 5, 6, 8, 9).

In addition, other information states:

"that some people view the birth event as an important event because it is a gift in life." (triangulation informant 7).

\subsection{Family perceptions about preparation for childbirth}

According to the main informants:

"the preparation of childbirth adjusted to the ability and understanding of each person, that is the preparation of funds and baby equipment, there is no standard whether the preparation of costs or other is appropriate, sufficient or not to deal with a delivery." (main informant 1,4 )

Only two informants who stated also:

"need self-preparation and mentally for the mother who will give birth and selfpreparation from the husband if one day his wife will give birth." (main informant 2,3)

The statement from the triangulation informant was almost the same as that conveyed by the main informant. Other additional statements include:

"carrying a KIS card for poor pregnant women and preparing transportation to deliver to health facilities." (triangulation infromant 5)

\subsection{Perceptions about who should help and where labor is carried out}

Of the four main informants, three gave the same statement, that:

"those who assisted in childbirth should be Midwives, because Midwives are considered people who have education, expertise and experience in their fields. Regarding the ideal place for delivery in the midwife's house or other health facilities". (main infromant 1, 3, 4)

A different statement was made by one main informant who said:

"it was better to help the delivery in the midwife, but the reality was that the midwife was called only to check the condition and inject the mother who had given birth with a traditional birth attenden while the good place to do labor is at home because it feels comfortable, many families are helping and assisting, if giving birth in the hospital many families are busy and have difficulty in transportation to visit her."(main infromant 2)

The results of interviews with triangulation informants, almost all of them gave statements that:

"those who should help in giving birth were midwives at the home of midwives/polindes. Midwives are ready to serve the community with the infrastructure that is owned, but there are 
some residents who choose childbirth assistance assisted by midwives who work in other villages." (triangulation informant $3,4,5,6,7,8,9$ )

A different statement was expressed by the triangulation informant who actually wanted the birth to be assisted by the Midwife and carried out at the midwife's house, but due to a misperception with the information delivered by the midwife during the pregnancy checkup, finally decided to stop checking and canceling her intention to give birth at the place the midwife.

Other information from the informant stated that:

"the midwife wanted to deliver the childbirth but the place of delivery was at her own home even though she had previously received information that the informant had to give birth at a health facility, because the condition of her pregnancy was at high risk." (triangulation infroman 1,2)

\subsection{Perceptions regarding childbirth performed at home}

Information from two main informants explained that:

"labor at home was due to several factors including, for example, pregnant women who had not been able to be taken to the health centre because they were close to delivery, at the family hospital the transportation costs would be constrained to visit. Giving birth at home will feel more comfortable because it is helped and accompanied by family relatives." (main infromant 1,2 )

Different information was revealed by two other key informants:

"The labor delivered at home was not safe and risky, both for the midwife and the mother who gave birth." (main infromation 34 )

The expression of two triangulation informants:

"an approve labor at home is because they feel they are used to it, surrender and accept whatever happens even though the informant actually does not know how to give birth with a traditional birth attendance. In addition, due to cost reasons, wanting to be practical, not bothering with the process of going to and returning from the midwife/polindes house, and there are neighbors who help when there are difficulties, find it easy to eat and drink and other necessities because it is available at home." (triangulation infromant 1,2 )

A statement from two triangulation informants:

"Refuse labor at home because labor at home felt the process felt longer, inconvenient for relatives, uneasy because many people, the experience of childbirth which was assisted by village traditional birth attendance and experienced difficulties and worry about the risks that could be faced. Information from other triangulation informants mentioned that, midwives only help themselves and feel difficulties with the limitations of helping deliveries at the patient's home. Locations of residents homes in remote areas will complicate the referral process if complications occur that must be treated at the hospital." (triangulation informant 3 , $4,5,6,7,8,9)$

\subsection{Perceptions of deliveries performed at health facilities and available infrastructure}

Information from two main informants that:

"they refused to give birth at a health facility despite having complete equipment due to cost constraints, not having a national health insurance (JKN card), and fearing not being visited by the family." (main informant 1,2 )

The statement differs from the other two informants that: 
"giving birth at home the midwife/polindes feels more comfortable and hassle-free, the distance is close, the equipment and medicines are quite complete if complications occur will be quickly detected and handled, but in the village concerned there is no ambulance if needed anytime." (main informant 3,4 )

Opinions from triangulation informants:

"not agree to give birth in other health facilities because they are afraid of actions to be taken at the hospital and the cost problem. Feeling ashamed and reluctant to Poskesdes/Puskesmas, because many Midwives and embarrassed to sound in pain when giving birth by someone else." (triangulation informant 1,2 )

The information provided by two triangulation informants:

"agreed to give birth in a health facility was due to its close proximity, no hassle, feeling more comfortable, calm and not worried. The midwife is always ready, fast and calm in handling." (triangulation informant 3,4)

Another statement was also conveyed by five triangulation informants that:

"when midwives help deliveries in health facilities it will feel safer because the atmosphere and conditions of special rooms make it easier to provide action, and can collaborate with colleagues or doctors of health centers if there are emergency cases." (triangulation informant 5, 6, 7, 8, 9)

\subsection{Perceptions about midwife readiness in providing services}

According to the three main informants:

"the midwife was considered good and was quick to respond when contacted when the wife wanted to give birth." (main informant 1, 3, 4)

Only one main informant:

"Rate the midwife as slow and incomplete in providing services." (main informant 2)

The statement given by the triangulation informant said that:

"the midwife was considered good, ready, alert, arrived on time and quickly to serve, and accepted the midwife's presence in the village, even though to serve the delivery, there were residents who used the services of the midwife who were outside the village." (triangulation infromant $1,2,3,4,6$ )

Other information by four triangulation infromant:

"the Village Midwife has tried to prepare herself as a helper with the infrastructure considered sufficient, although there are still shortcomings. One midwife does not occupy a polindes, because the condition of polindes is considered insufficient for a place of service as well as a residence of a midwife who has a family so that the service is carried out in her private home." (triangulation informant 5, 7, 8, 9)

\subsection{Perceptions of factors that influence the decision to choose the place of delivery}

According to the four main informants said:

"the influencing factors in deciding to choose the place of delivery, among others, are economic factors, ignorance and lack of awareness of the importance of clean, safe, and comfortable labor with a place of birth." (main informant 1, 2, 3, 4)

Information from all triangulation informants, that:

"they were involved in making these decisions, and there are several things that affect the process, that is, economic aspects, attitude and willingness factors, distance to the health facility, the influence of parents, cultural elements, habits / traditions, and knowledge factors". 


\subsection{Perceptions about the delivery of childbirth assistance in health facilities}

Some of the main informants (two main informant):

"never get counseling or explanation about it because they are busy with their work and when carrying out their wives doing an inspection of informants outside the room. One other key informant revealed their initiative to ask the midwife to confirm information he had heard from other residents." (main informant 1,2 )

Information from other main informants said that:

"they received the intended socialization from pregnant mothers' class activities, counseling at posyandu and during pregnancy check-up visits to the midwife's place." (main informant 3,4 )

Information from nain triangulation informants about the socialization of childbirth assistance programs in health facilities is:

"obtained from other health workers, reading from the Maternal and Child Health $(\mathrm{MCH})$ book, classes of pregnant women, posyandu, yasinan mothers, when conducting examinations at the midwife's home or puskesmas and information from neighbors. In addition, in village meetings or cross-sectoral meetings information was also provided about instructions and commitments between the Government and the Health Office for the delivery of delivery assistance in health facilities as well as the Jampersal program. In the P4K (Childbirth Planning and Prevention Complications Program) activity is constrained when the question of who plans and where pregnant women will give birth, the community is somewhat reluctant and confused to give answers to the Midwife."

\section{Discussion}

\subsection{Family views about the events of childbirth}

There are similar and different perceptions about childbirth obtained from informants because they are influenced by factors of education, work, needs, experience, attitudes, individual personality, and general belief in officers, and self-acceptance. According to reference mentioned that the higher a person's education the greater his awareness of health, and vice versa the lower a person's education, his understanding of health can be lower. The level of education affects someone to think and decide on something, basically they only look for comfort during labor without thinking about their own safety [6].

\subsection{Family perceptions about preparation for childbirth}

In connection with family preparation in preparation for childbirth to clean and safe deliveries, health workers in the village can maximize the P4K (Childbirth Planning and Prevention Complications Program) activities for every pregnant woman / family by increasing cadre collaboration and partnerships with village shamans and other sectors, as mentioned by Siskha (2017), that the implementation of the P4K (Birth Control and Prevention Complications Program) program has a contribution in helping pregnant women prepare for labor and reducing the MMR (Maternal Mortality Rate) needs to be reviewed in various aspects [7].

\subsection{Perceptions about who should help and where labor is carried out}

Health workers must provide an explanation of the importance of delivery assistance performed by competent health workers and performed in health facilities, on the 
implementation of $\mathrm{P} 4 \mathrm{~K}$ during early pregnancy checks or routine ANC visits by considering several aspects in providing IEC (communication, information, education) to clients, for example from educational background, work, social culture and other aspects of psychology by using language that can be understood by pregnant women and families.

Midwife competence must also be improved in terms of service to clients, skills or skills, and appearance and attitude so that clients feel comfortable and safe to be handled by officers. This is consistent with Fitria's (2014) study which stated that respondents who gave birth in health facilities or did not have good relations with health workers or traditional healers. This shows that both the health worker and the dukun can influence the respondent in determining the place of birth. If the level of closeness is closer to the health worker, trust in his input will appear otherwise if the respondent has a better closeness to the anttendance he will trust the input given by the traditional birth attendance [8].

\subsection{Perceptions regarding childbirth performed at home}

Obstacles faced by midwives in providing delivery assistance at patients' homes need to be explained so that they can get an idea of the risks and risks of childbirth assistance in a place that does not meet the requirements, advantages and advantages of labor at a health facility. The role of the village shaman functions as a companion in the birth process rather than as a main helper, helping care for infants and postpartum mothers in accordance with their role, working on matters related to customs or culture as long as it does not conflict with health, so that when the village shaman is called by the family, it remains contact the midwife to work together to deliver labor.

If there is a condition that the patient cannot be brought to the health facility, the Midwife must be prepared with the equipment that has been prepared in advance without worrying about the equipment or medicines left behind. This is in accordance with research Prasetyawati, (2012) which revealed that the fact that there are still birth rates at home, demands the need for optimizing the empowerment of existing facilities and health workers to conduct childbirth assistance. Therefore, there must be proper preparation, good preparation of helpers, tools and materials as well as medicines carried by the helper, preparation of a place, a clean base and a safe environment and assistance by the patient's family [9].

\subsection{Perceptions of deliveries performed at health facilities and available infrastructure}

Other steps that can be taken are evaluating and improving the quality of services that have been carried out both from infrastructure facilities, ways of service and the service provider himself. Increasing cross-sectoral collaboration with community leaders, religious leaders, PKK officials and other health cadres to promote service activities related to maternal and child health, further maximize the activities of the $\mathrm{MCH}$ program socialization, especially regarding delivery assistance by health workers and utilization of health facilities and Jampersal programs (Childbirth Guarantee) for poor families, discussing waiting houses or planning transportation for pregnant women in remote and difficult areas. Reactivating the polindes function as a health service facility by using service hours that are tailored to the needs and agreements with the community. Guidance and supervision from puskesmas to improve and improve the quality of services both for staff and infrastructure. As found in Triani's (2010) study community affordability including distance to health facilities will influence the choice of health services, accessibility such as types of services, available health workers and opening hours [10]. 


\subsection{Perceptions about midwife readiness in providing services}

Midwives should carry out their main duties, roles and functions with full responsibility, treating all clients equally regardless of social, cultural, economic, and religious status. Build communication and establish good cooperation with peers, cadres and village shamans, as well as improve midwives' skills and competencies by attending training and improving service quality by improving performance and always applying the $5 \mathrm{~S}$ culture (smile, greetings, greetings, courtesy, polite) each providing services to the community. Regarding equipment that is not owned or damaged, it will be proposed to procure it to the district health office, officers should evaluate equipment, materials and medicines regularly to keep the stock in a ready condition whenever needed.

\subsection{Perceptions of factors that influence the decision to choose the place of delivery}

Midwives play an important role in making acceptable strategies and guidelines in helping families make their birth planning and decisions. For example, improving service quality, making service packages that can be selected by families, and working with other sectors for administrative equipment for poor families. This is partly the same in Rahmaniah's research (2014), namely, factors related to the decision to choose the place of delivery including family roles, income, price / tariff of service, location / place, promotion of service [11].

\subsection{Perceptions about the delivery of childbirth assistance in health facilities}

Maximizing more specific and focused IEC activities such as the P4K program and pregnant mother classes by actively involving the husband or immediate family accompanying them Maximizing activities funded by the BOK (Health Operational Assistance) program, and socializing the Jampersal program.

This situation is in line with what was stated by Yulifah (2009) that midwifery counseling is a process of learning, fostering good relations, providing assistance, and forms of cooperation carried out professionally in accordance with their fields by Midwives to clients to solve problems, overcome obstacles to development and meet client needs. Preparations for pregnancy and supporting mothers in labor so that the mother understands her self better and can make the right decisions [12].

\section{Conclusion}

The results of the study stated that family perceptions about childbirth is an important event in life which includes feelings of sadness, fear and anxiety so that it is necessary to prepare who will be chosen to be a helper and place of delivery, therefore many factors can influence the decision making, namely economics, acceptance of midwives, feeling of security, comfort and ease with the chosen place of delivery, awareness of the safety of mothers and infants and IEC received. Although childbirth is assisted by competent personnel and located in a health facility, the reality is that there are still pregnant women who give birth at home and are assisted by the shaman so that the role of IEC in the implementation of P4K (Childbirth Planning and Prevention Complications Program) activities at the initial pregnancy 
visit and every ANC visits need to be increased again without ignoring other factors that contribute to the implementation of the program and maximize programs that have been running for the achievement of improving maternal / infant health and well-being and decreasing maternal and infant mortality rates.

\section{Acknowledgments}

Thank you, STIKES Sari Mulia, for granting permission to conduct research and thanking the leadership of the Tanjung Health Center for giving permission and data to carry out research in the Tanjung Health Center working area.

\section{Reference}

[1] Kementerian Kesehatan RI. 2013. Profil Kesehatan Indonesia. Jakarta: Kementerian Kesehatan RI.

[2] Kementerian Kesehatan RI. 2015. Profil Kesehatan Indonesia. Jakarta: Kementerian Kesehatan RI.

[3] Kementerian Kesehatan RI. 2011. Peraturan Menteri Kesehatan Republik Indonesia Nomor 2562/Menkes/Per/xii/2011 Tentang Petunjuk Teknis Jaminan Persalinan. Jakarta: Kementerian Kesehatan RI

[4] Puskesmas Kecamatan Tanjung. 2015. Laporan PWS Kesehatan Ibu dan Anak. Tanjung: Kecamatan Tanjung.

[5] . 2016. Laporan PWS Kesehatan Ibu dan Anak. Tanjung: Kecamatan Tanjung.

[6] Khudhori. 2012. Analisis Faktor-faktor yang Mempengaruhi Keputusan Pemilihan Tempat Persalinan Pasien PoliKlinik Kandungan dan Kebidanan RS IMC Bintaro [Tesis]. Depok. Universitas Indonesia.

[7] Siskha, Herlina. 2017. Pelaksanaan P4K (Program Perencanaan Persalinan Dan Pencegahan Komplikasi) Dalam Menurunkan Angka Kematian Ibu Di Puskesmas Imogiri 1 Bantul Yogyakarta [tesis]. Yogyakarta. Universitas Aisyiyah.

[8] Fitria Nurlinda. 2012. Pengaruh Faktor Karakteristik Individu, Psikologi dan Sosial Terhadap Pemilihan Tempat Persalinan di Fasilitas Kesehatan Wilayah Kecamatan Muara Ancalong. Kutai [tesis]. Surabaya: Universitas Airlangga.

[9] Prasetyawati, Arsita Eka. 2012. Kesehatan Ibu dan Anak (KIA) dalam Millenium Develoment Goals (MDG'S). Yogyakarta : Nuha Medika.

[10] Triani, Wulan Sari. 2010. Analisis Spasial Pemilihan Tempat Pertolongan Persalinan Di Kelurahan SendangMulyo Semarang. J. Kesehatan Reproduksi. 1(3). 113-124

[11] Rahmaniah, Fauzia. 2014. Faktor-faktor Yang Berhubungan Dengan keputusan Pemilihan Tempat Persalinan Pasien Poliklinik Kandungan Dan Kebidanan Di Rumah Sakit Ibu Dan Anak Kemang Medical Care Tahun 2014. [skripsi]. Jakarta. UIN Syarif Hidayatullah.

[12] Yulifah. 2009. Komunikasi dan Konseling Dalam Kebidanan. Jakarta: Salemba Medika 